\title{
ANALISIS ANGKUTAN SEDIMEN DASAR (BED LOAD) PADA SALURAN IRIGASI MATARAM YOGYAKARTA
}

\author{
Anggi Hermawan ${ }^{1, *}$, Erwin Nur Afiato ${ }^{2}$ \\ ${ }^{1, *)}$ Program Studi Teknik Sipil, Institut Teknologi Nasional Yogyakarta, Yogyakarta \\ Email: anggi@itny.ac.id \\ ${ }^{2}$ Program Studi Teknik Sipil, Institut Teknologi Nasional Yogyakarta, Yogyakarta \\ Email: erwin.nur@itny.ac.id
}

\begin{abstract}
In the last decade, the problem that has occurred in the Yogyakarta Mataram irrigation channel is sedimentation in the channel. This impacts reducing the cross-sectional discharge capacity of the canal and resulting in the supply of irrigation discharged to agricultural areas to be not optimal so that agricultural productivity in the Mataram Irrigation Area will also not be optimal. The sediment transport (bedload) in an open channel can be approached using the empirical equation, including the Einstein, Meyer - Peter Muller, and Frijlink equations. Sediment transport events that occur in the channel are stated based on the magnitude of the flow shear stress exceeding the sediment particles' critical shear stress. The quantity of sediment transport in the channel is expressed in the logarithmic curve of the relationship between the Froude number (fr) to the sediment transports $(q b)$. The curve explains that the increase in the Froude number (fr) that occurs on each section of the channel will be directly proportional to the rise in the quantity of transport sediment (qb). The most significant sediment transport occurred at the Gambang and Nambongan channel section site, predicting sediment transport of $3.57 \mathrm{~m} 3 /$ day and $3.67 \mathrm{~m} 3 /$ day, respectively. Thus, the potential for sediment transport that will settle in the downstream area is $3.67 \mathrm{~m} 3 /$ day.
\end{abstract}

Keywords: sedimentation, sediment transport

\section{PENDAHULUAN}

Saluran irigasi Mataram mengairi 5200 hektar areal pertanian. Intake saluran irigasi ini berada pada Sungai Progo dan mengalir sejauh kurang lebih $32 \mathrm{~km}$ hingga bertemu dengan Sungai Opak di sisi timur Kota Yogyakarta. Saluran irigasi Mataram menjadi sumber air bagi aktivitas pertanian masyarakat pada daerah yang dilalui.

Peraturan Menteri Pekerjaan Umum No.12/PRT/M/2015 tentang Pedoman dan Pemeliharaan Jaringan Irigasi menjelaskan bahwa "Pemeliharaan jaringan irigasi adalah upaya menjaga dan mengamankan jaringan irigasi agar selalu dapat berfungsi dengan baik guna memperlancar pelaksanaan operasi dan mempertahankan kelestariannya melalui kegiatan perawatan, perbaikan, pencegahan dan pengamanan yang harus dilakukan secara terus menerus". Salah satu pekerjaan pemeliharaan saluran irigasi adalah pengerukan endapan sedimen yang terdapat pada ruas penampang saluran irigasi. Sedimentasi yang terjadi pada saluran irigasi Mataram menjadi masalah yang perlu ditangani karena dapat mengakibatkan pengurangan kapasitas debit pada penampang saluran irigasi. Adanya pengurangan kapasitas debit dapat memberikan dampak penurunan produksi pertanian ataupun gagal panen.

Pada dasarnya, sangat sulit untuk mengamati pergerakan partikel sedimen di dalam saluran. Angkutan sedimen pada saluran terbuka dapat didekati dengan menggunakan persamaan empirik, diantaranya adalah Persamaan Einstein, Meyer - Peter Muler dan Frijlink. Beberapa perasamaan tersebut banyak digunakan dalam memprediksi kuantitas angkutan sedimen dan besarnya 
laju sedimentasi (sediment yield) yang terjadi pada saluran terbuka

Beberapa kajian yang telah dilakukan sebelumnya terkait potensi angkutan sedimen pada saluran terbuka diantaranya adalah Suryawan (2008) yang mengkaji tentang kuantitas angkutan sedimen pada saluran terbuka berdasarkan ketidakseragaman material. Penelitian dilakukan di laboratorium dengan menggunakan flume sepanjang $10 \mathrm{~m}$ dan lebar $0,6 \mathrm{~m}$ serta pengaturan kemiringan disesuaikan dengan kondisi batas tertentu. Pengujian hidrolika pada flume dilakukan berdasarkan 3 jenis material dasar dengan variasi debit dan kemiringan saluran. Hasil dari pengujian laboratorium menunjukan bahwa angkutan sedimen dasar sangat dipengaruhi oleh distribusi ukuran material dasar asli dan distribusi ukuran angkutan sedimen dasar. Hal tersebut disebabkan pengaruh ukuran relatif butiran lebih besar daripada pengaruh ukuran abslolut butiran, oleh karena itu proporsi setiap ukuran fraksi butiran tidak seragam sangat penting peranannya pada penentuan angkutan sedimen dasar pada saluran dan sungai alam.

Putra et al. (2016) mengkaji tentang analisis sedimentasi pada saluran utama Bendung Jangkok. Penelitian dilakukan dengan metode pengukuran langsung di lapangan dan analisis laboratorium yang meliputi pengujian berat jenis sampel sedimen dasar, gradasi butiran, dan pengujian konsentrasi kandungan sedimen suspended load. Sedangkan perhitungan kuantitas angkutan sedimen dilakukan dengan persamaan Meyer-Peter Muler (M.P.M) dan Einstein. Berdasarkan persamaan metode M.P.M., angkutan sedimen pada saluran utama Bendung Jangkok diperoleh sebesar 5,984 $\mathrm{x} 10^{-3} \mathrm{~m}^{3} /$ hari. Sedangkan berdasarkan persamaan Einstein diperoleh sebesar 6,843 $\mathrm{x} 10^{-2} \mathrm{~m}^{3} /$ hari.

Afiato (2016) mengkaji tentang distribusi kecepatan aliran dan konsentrasi sedimen pada aliran tidak seragam pada saluran irigasi Mataram Yogyakarta. Penelitian dilakukan dengan metode eksperimen langsung di lapangan dimana pengukuran dan pengambilan data langsung dilaksanakan di lapangan pada saluran yang dipersempit dan saluran diperlebar berdasarkan metode pengambilan data point integrated sampling. Sedangkan kecepatan aliran diukur dengan menggunakan alat Propeller Currentmeter dan konsentrasi sedimen suspensi diukur dengan menggunakan alat Opcon. Dari hasil penelitian menunjukan bahwa konsentrasi sedimen suspensi semakin besar ketika mendekati dasar saluran dan konsentrasi sedimen suspensi rata-rata vertikal cenderung semakin besar ke area tengah penampang saluran.

Maini (2016) melakukan penelitian tentang distribusi konsentrasi sedimen suspensi pada belokan saluran terbuka tampang trapesium dengan studi kasus pada saluran irigasi Mataram Yogyakarta. Penelitian dilakukan dengan metode eksperimen langsung di lapangan pada 3 lokasi belokan saluran terbuka dengan sudut dan jari-jari belokan yang bervariasi dengan bentuk penampang trapesium. Kecepatan aliran diukur dengan menggunakan alat Propeller Currentmeter dan konsentrasi sedimen suspensi diukur dengan menggunakan alat Opcon. Hasil penelitian menunjukan bahwa konsentrasi sedimen suspensi rata - rata tampang pada inner bank cenderung lebih besar daripada di outer bank. Nilai konsentrasi sedimen suspensi berdasarkan pengukuran kecepatan rata-rata vertikal yang diperoleh pada inner bank sebesar 0,27 dan pada outer bank sebesar 0,86.

Berdasarkan latar belakang tersebut diperlukan penelitian ini yang bertujuan untuk memperhitungkan kuantitas angkutan sedimen yang terjadi pada saluran irigasi utama Mataram Yogyakarta yang berpotensi menjadi sedimentasi pada ruas penampang saluran yang dapat mengganggu kinerja dari saluran irigasi Mataram.

\section{Angkutan Sedimen pada Saluran Irigasi}

Angkutan sedimen pada saluran terbuka sangat erat kaitannya dengan kondisi Daerah Aliran Sungai (DAS). Perilaku manusia juga 
menjadi pemicu utama terhadap terjadinya erosi pada lahan dan berdampak terhadap terjadinya sedimentasi. Permasalahan sedimentasi di Indonesia lebih didominasi oleh aliran air yang mengangkut tanah hasil erosi dan mengendap di dalam waduk, sungai, saluran irigasi, di atas tanah pertanian, muara sungai dan lain sebagainya (Suparman, 2011). Peningkatan besarnya jumlah sedimen (sediment yield) juga disebabkan oleh besarnya frekuensi aliran puncak sebagai respon terhadap permukaan dasar saluran yang tidak tahan atau rentan terjadinya erosi (Stanley, 1997). Erosi semakin besar terjadi pada saat hujan pada awal musim setelah musim kemarau. Hal tersebut disebabkan oleh peningkatan curah hujan yang dapat mengerosi lapisan permukaan tanah dan menjadi aliran permukaan (run off). (Carter et al., 1976)

\section{Persamaan Awal Gerak Partikel Butiran Sedimen}

Angkutan sedimen pada dasar saluran sangat dipengaruhi oleh awal gerak butiran partikel sedimen pada saat tegangan kritis nya terlampaui. Ketika tegangan geser belum melampaui nilai tegangan kritis, maka material dasar akan diam atau tak bergerak. Sangat sulit untuk mengukur gerakan partikel pada dasar saluran, hal tersebut disebabkan karena gerakan partikel sedimen merupakan fenomena yang acak dalam ruang dan waktu (Simons et al., 2004).

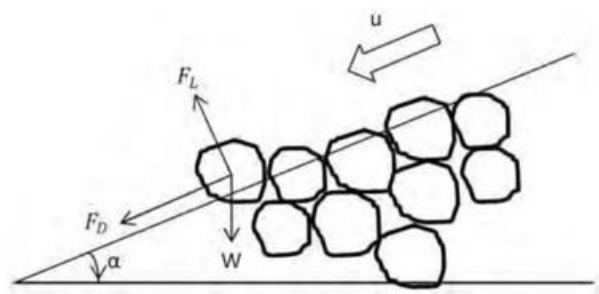

Gambar 1. Parameter awal gerak partikel butiran sedimen

Faktor - faktor yang berkaitan dengan awal gerak butiran sedimen adalah kecepatan aliran, diameter ukuran butiran, gaya angkat yang lebih besar dari gaya berat butiran, dan gaya geser kritis. Gaya - gaya yang bekerja pada partikel sedimen non-kohesiv dijelaskan pada Gambar 1 (Hassanzadeh, 2012).

Tegangan geser aliran $\left(\tau_{0}\right)$ merupakan tegangan yang ditimbulkan akibat adanya gaya pergerakan aliran, dimana gaya yang terjadi merupakan kecepatan geser aliran $\left(\boldsymbol{u}_{*}\right)$ yang dinyatakan dengan persamaan (1).

$u_{*}=\sqrt{g \cdot R \cdot S}$

dengan,

$\mathrm{g}=$ percepatan gravitasi,

$\mathrm{R}=$ radius hidraulik penampang saluran,

$\mathrm{S}=$ kemiringan dasar saluran.

Tegangan geser aliran $\left(\tau_{0}\right)$ dinyatakan dengan persamaan (2).

$\tau_{0}=\rho_{w} \cdot u_{*}{ }^{2}$

dengan,

$\tau_{0}=$ tegangan geser aliran $\left(\mathrm{N} / \mathrm{m}^{2}\right)$,

$\rho_{w}=$ berat jenis air $\left(\mathrm{kg} / \mathrm{m}^{3}\right)$,

$u_{*}=$ kecepatan geser aliran $(\mathrm{m} / \mathrm{det})$.

Awal gerak butiran sedimen dipengaruhi oleh besarnya nilai tegangan geser aliran $\left(\tau_{0}\right)$ yang terjadi pada ruas penampang aliran dan tegangan geser kritik $\left(\tau_{c}\right)$. Partikel sedimen akan bergerak apabila:

1) $\tau_{0}<\tau_{c}$, maka butiran sedimen dalam kondisi tak bergerak atau diam,

2) $\tau_{0}=\tau_{c}$, maka butiran mulai bergerak,

3) $\tau_{0}>\tau_{c}$, maka butiran sedimen bergerak.

Nilai tegangan geser kritik dinyatakan pada persamaan (3).

$\tau_{c_{*}}=\frac{\tau_{c}}{\left(\rho_{s}-\rho_{w}\right) D_{s}}$

dengan,

$\tau_{c_{*}}=$ parameter tegangan geser,

$D_{S}=$ diameter ukuran butiran (m),

$\rho_{S}=$ berat jenis butiran sedimen $\left(\mathrm{kg} / \mathrm{m}^{3}\right)$.

Nilai parameter tegangan geser $\left(\boldsymbol{\tau}_{\boldsymbol{c}_{*}}\right)$ ditentukan melalui kurva diagram pergerakan partikel butiran sedimen Shields yang didasarkan terhadap nilai Reynolds Number $(R e)$. Bilangan Reynold merupakan faktor tak 
berdimensi yang dinyatakan dengan persamaan (4).

$R_{e}=\frac{u_{*} \cdot D_{s}}{v}$

dengan,

$R_{e}=$ bilangan Reynolds,

$u_{*}=$ kecepatan geser $(\mathrm{m} / \mathrm{dt})$,

$D_{s}=$ diameter ukuran butiran sedimen (m),

$v=$ viskositas $\left(\mathrm{m}^{2} / \mathrm{det}\right)$.

\section{Persamaan Angkutan Sedimen}

Einstein (1950) menurunkan persamaan angkutan sedimen berdasarkan teori statistik dan hasil pengamatan eksperimental di laboratorium dimana pergerakan partikel sedimen yang terjadi pada dasar aliran disebabkan oleh adanya gaya angkat (uplift force) yang lebih besar daripada berat massa partikel sedimen di dalam air. Debit angkutan sedimen dasar $\left(\mathrm{q}_{\mathrm{b}}\right)$ dinyatakan dalam persamaan (5).

$q b=\Phi * x \sqrt{\left[\frac{\rho s-\rho w}{\rho w}\right] \times g \times D} \times \rho s$

dengan, $q b=$ total sedimen dasar per meter lebar saluran $(\mathrm{kg} / \mathrm{m}$.det),

$\Phi *=$ intensitas angkutan sedimen,

$\rho_{w} \quad=$ rapat massa air $\left(\mathrm{kg} / \mathrm{m}^{3}\right)$,

$\rho_{S} \quad=$ rapat massa sedimen $\left(\mathrm{kg} / \mathrm{m}^{3}\right)$,

$\mathrm{g} \quad=$ percepatan gravitasi $\left(\mathrm{m} / \mathrm{s}^{2}\right)$,

$\mathrm{D}_{35}=$ diamter butiran sedimen $(\mathrm{m})$.

Nilai parameter intensitas angkutan sedimen $(\Phi *)$ ditentukan berdasarkan nilai parameter intensitas aliran atau tegangan geser aliran $(\psi *)$ yang dinyatakan dalam kurva hubungan intensitas angkutan sedimen $(\Phi *)$ dan intensitas aliran atau tegangan geser aliran $(\psi *)$ pada Gambar 2. Nilai parameter intensitas aliran ditentukan melalui Persamaan (6).

$\psi_{*}=\frac{\left(\rho_{s}-\rho_{w}\right)}{\rho_{w}} \cdot \frac{d}{\mu \cdot R h . S}$

dengan,

$d=$ diameter butiran sedimen ( $\mathrm{mm})$,

$R_{h} \quad=$ radius hidraulik penampang saluran (m),

$S=$ kemiringan dasar saluran,

$\mu=$ parameter kondisi dasar saluran.

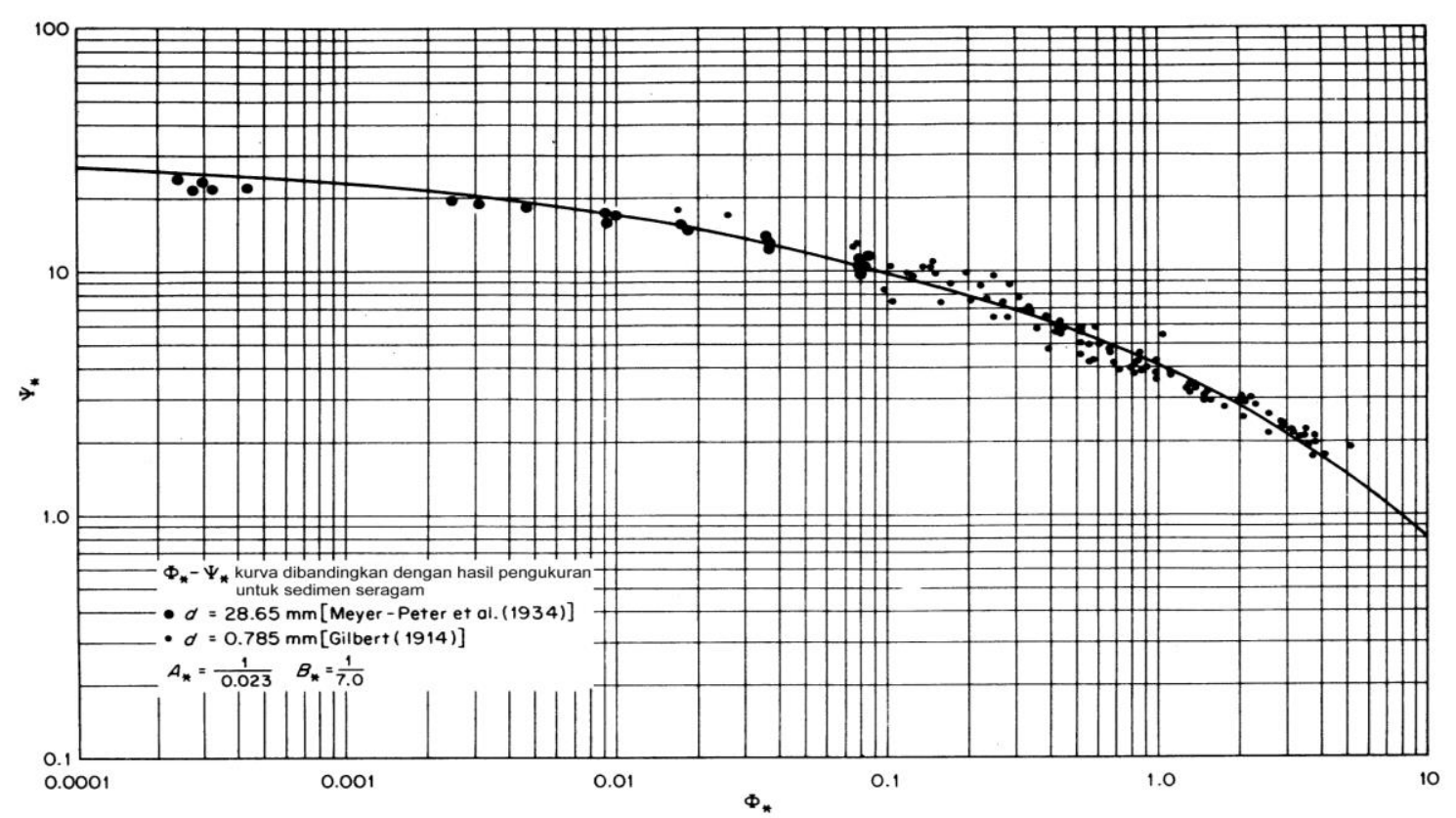

Gambar 1. Grafik parameter angkutan sedimen (Einstein, 1950)

Meyer-Petter Muller (1948) menurunkan persamaan angkutan sedimen dimana prinsip dari pergerakan sedimen didasarkan akibat adanya kemiringan energi. Massa angkutan sedimen $\left(g_{s b}^{\prime}\right)$ dinyatakan dalam bobot terendam dalam satuan $(\mathrm{kg} / \mathrm{s} / \mathrm{m})$ yang 
dinyatakan pada persamaan (7). Sedangkan debit angkutan sedimen $\left(\mathrm{q}_{\mathrm{sb}}\right)$ dinyatakan pada persamaan (8).

$$
0,25 \rho^{1 / 3} \frac{\left(g_{s b}^{\prime}\right)^{2 / 3}}{\left(\rho_{s}-\rho\right)}=\frac{\rho \cdot R_{h} \cdot \mu \cdot S}{\left(\rho_{s}-\rho\right) d}-0,047
$$

$q_{s b}=\frac{g_{s b}^{\prime}}{\left(\rho_{s}-\rho\right) \cdot g}$

dengan,

$q_{s b}=$ total sedimen dasar per meter lebar saluran $\left(\mathrm{m}^{3} / \mathrm{det} / \mathrm{m}\right)$

$\mu=$ faktor kekasaran dasar saluran (ripple factor)

$\rho_{w}=$ rapat massa air $\left(\mathrm{kg} / \mathrm{m}^{3}\right)$,

$\rho_{S}=$ rapat massa sedimen $\left(\mathrm{kg} / \mathrm{m}^{3}\right)$,

$\mathrm{g}=$ percepatan gravitasi $\left(\mathrm{m} / \mathrm{s}^{2}\right)$,

$\mathrm{d}=$ diamter butiran sedimen ( $\mathrm{mm}$ ),

$R_{h}=$ radius hidraulik penampang saluran (m),

$\mathrm{S}=$ kemiringan dasar saluran .

Frijlink (1952) (dalam Istiarto, 2014) menurunkan persamaan dalam memperhitungkan kuantitas angkutan sedimen dasar (bed load) yang dinyatakan pada persamaan (9)

$$
\begin{aligned}
\Phi_{*} & =\frac{q_{s b}}{d_{m} \sqrt{g \cdot \mu \cdot R_{h} \cdot S_{0}}} \\
& =5 \exp \left[-0,27\left(\frac{\rho_{s}-\rho}{\rho}\right) \frac{d_{m}}{\mu \cdot R_{h} \cdot S_{0}}\right]
\end{aligned}
$$

Dimana nilai $\Phi_{*}$ merupakan parameter intensitas angkutan sedimen yang memiliki hubungan empiris terhadap parameter intensitas aliran / tegangan geser aliran $\left(\psi^{\prime}\right)$ yang dinyatakan pada persamaan (10).

$\psi^{*}=\frac{\left(\rho_{s}-\rho\right) \cdot d_{50}}{\mu \cdot R_{h} \cdot S_{0}}$

Parameter kondisi dasar saluran $(\mu)$ dinyatakan sebagai rasio kekasaran dasar dengan kekasaran pada partikel butiran sedimen yang dinyatakan dalam persamaan (11).

$\mu=\left(\frac{C}{C_{d 90}}\right)^{3 / 2}$

Nilai parameter kekasaran dasar $(C)$ dan friction factor $\left(C_{d 90}\right)$ ditentukan dengan persamaan Chezy yang dinyatakan dalam persamaan (12) dan (13)

$$
\begin{aligned}
& C=18 \log \frac{12 h}{k} \\
& C_{d 90}=18 \log \frac{12 h}{d_{90}}
\end{aligned}
$$

dengan,

$\mathrm{k}=$ ketinggian kekasaran hidraulik dasar saluran (m),

$\mathrm{d}_{90}=$ diameter ukuran butiran $(\mathrm{mm})$.

Tinggi kekasaran hidraulik saluran ditentukan melalui persamaan (14).

$u_{z}=5.75 u_{*} \log \left(\frac{33 h}{k_{s}}\right)$

dengan,

$\mathrm{u}_{\mathrm{z}}=$ kecepatan aliran $(\mathrm{m} / \mathrm{det})$,

$\mathrm{h}=$ kedalaman aliran $(\mathrm{m})$,

$\mathbf{u}_{*}=$ kecepatan geser aliran $(\mathrm{m} / \mathrm{det})$,

$\mathrm{k}_{\mathrm{s}}=$ ketinggian kekasaran hidraulik dasar saluran (m).

\section{METODE PENELITIAN}

Untuk mendapatkan kuantitas angkutan sedimen proses analisis diawali dengan tahap pengumpulan data. Data yang diperlukan untuk menghitung kuantitas angkutan sedimen adalah data profil aliran pada ruas penampang, penampang saluran dan data ukuran butiran sedimen. Langkah selanjutnya adalah melakukan analisis data untuk mendapatkan ukuran butiran sedimen melaui data sedimen.

\section{Kontrol Kestabilan Dasar Saluran}

Kestabilan dasar saluran merupakan kondisi keseimbangan partikel sedimen terhadap gaya-gaya yang bekerja pada aliran. Gerakan partikel sedimen ditentukan melalui persamaan awal gerak partikel sedimen seperti yang telah dituliskan pada persamaan (2) dan persamaan (3). Prinsip dari awal gerak partikel sedimen adalah bahwa partikel sedimen akan bergerak dan menyebabkan terjadinya angkutan sedimen apabila kondisi tegangan geser aliran $\left(\tau_{0}\right)$ melampaui dari tegangan geser kritik partikel $\left(\tau_{c}\right)$. 
Sedangkan kondisi sebaliknya dapat dinyatakan sebagai peristiwa sedimentasi pada ruas saluran yang ditinjau.

\section{Perhitungan Kuantitas Angkutan Sedimen}

Kuantitas angkutan sedimen dasar (bed load) ditentukan melalui pendekatan empirik dengan menggunakan persamaan Einstein, Meyer-Peter Muller, dan Frijlink. Dari ketiga persamaan tersebut dapat dijadikan sebagai dasar dalam memprediksi besarnya debit angkutan sedimen pada ruas penamapang yang ditinjau.

\section{Data Sedimen}

Data ukuran butiran sedimen dalam memperhitungkan angkutan sedimen merupakan data sekunder yang diperoleh melalui data penelitian sebelumnya yang dilakukan oleh Afiato (2016). Sampel sedimen diambil di beberapa titik lokasi penampang saluran yang telah dilakukan pengujian analisis saringan. Data representasi ukuran butiran sedimen pada salah satu lokasi penampang saluran disajikan pada Gambar 3.

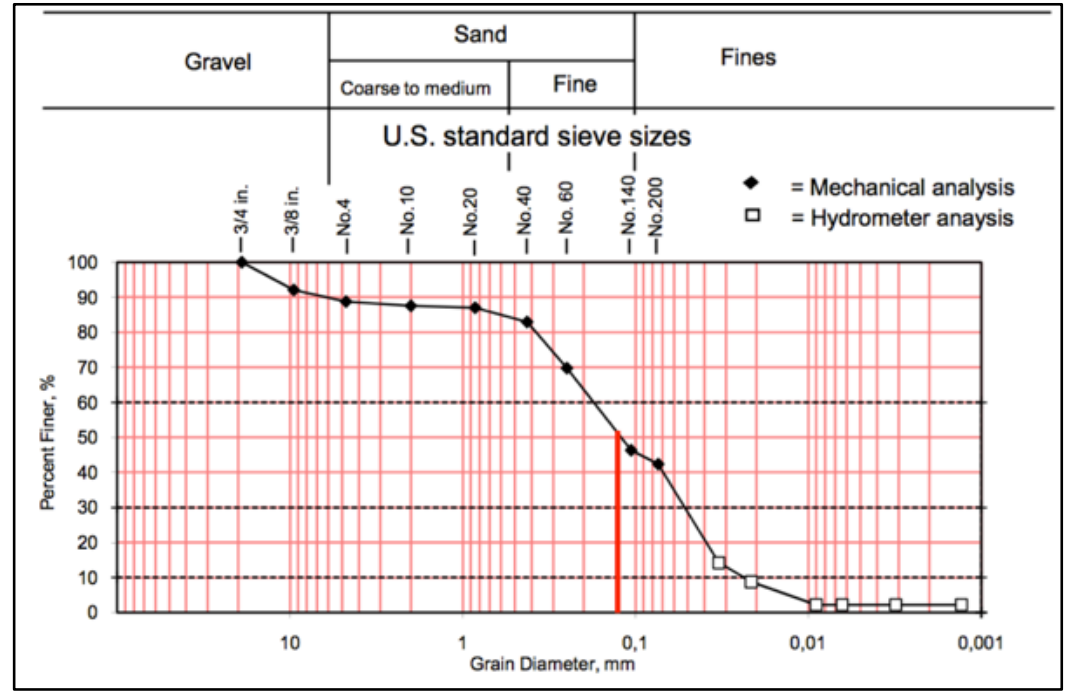

Gambar 3. Kurva distribusi ukuran butiran sedimen dasar saluran

\section{Data Profil Aliran dan Penampang Saluran}

Data profil aliran dan penampang saluran merupakan data sekunder yang diperoleh berdasarkan data penelitian sebelumnya yang dilakukan oleh Afiato (2016). Data profil dan penampang saluran menjelaskan tentang dimensi profil aliran dan dimensi penampang melintang saluran pada masing-masing lokasi pengukuran. Penampang saluran irigasi yang ditinjau berbentuk trapesium dengan profil dimensi penampang pada masing-masing lokasi dapat dilihat pada Tabel 1.

\section{HASIL DAN PEMBAHASAN}

\section{Kontrol Kestabilan Dasar}

Angkutan sedimen yang terjadi pada ruas penampang saluran dibuktikan dengan kondisi kestabilan partikel sedimen dasar saluran. Dengan prinsip bahwa material partikel butiran di dalam air mulai bergerak akibat tegangan geser aliran ( $\left.\boldsymbol{\tau}_{\mathbf{0}}\right)$ yang melampaui nilai tegangan kritiknya $\left(\boldsymbol{\tau}_{\boldsymbol{c}}\right)$. Istiarto (2014) menjelaskan bahwa apabila gaya-gaya aliran berada di bawah nilai kritisnya, maka butir sedimen dalam kondisi tidak bergerak disebut sebagai rigid bed. Kondisi ini memungkinkan terjadinya pengendapan atau sedimentasi pada ruas saluran. Sedangkan apabila gaya aliran 
melebihi nilai kritisnya, maka butir sedimen akan bergerak dan dasar saluran dalam kondisi bergerak atau disebut sebagai erodible bed. Kondisi ini memungkinkan terjadinya erosi pada dasar saluran yang ditinjau. Kontrol kestabilan dasar atau partikel butiran terhadap tegangan geser aliran $\left(\boldsymbol{\tau}_{\mathbf{0}}\right)$ ditentukan melalui persamaan (2) dimana tegangan geser aliran $\left(\boldsymbol{\tau}_{\mathbf{0}}\right)$ merupakan fungsi dari kecepatan geser aliran $(u *)$ yang ditentukan melalui persamaan (1). Sedangkan nilai tegangan geser kritik $\left(\boldsymbol{\tau}_{\boldsymbol{c}}\right)$ ditentukan berdasarkan persamaan (3) dimana nilai parameter tegangan geser kritik $\left(\boldsymbol{\tau}_{\boldsymbol{c} *}\right)$ ditentukan melalui Diagram Shields yang didasarkan terhadap Reynold Number $(R e)$. Hasil dari analisa kestabilan material dasar pada masing-masing lokasi penampang saluran dapat dilihat pada Tabel 2.

Tabel 1. Data profil aliran dan penampang saluran

\begin{tabular}{|c|c|c|c|c|c|c|c|c|c|}
\hline \multirow{2}{*}{ Lokasi } & $\begin{array}{c}\text { Bentuk } \\
\text { Penampang }\end{array}$ & $\begin{array}{c}\text { Lebar } \\
\text { Dasar }\end{array}$ & $\begin{array}{c}\text { Kedalaman } \\
\text { Aliran } \\
\text { Pengukuran }\end{array}$ & $\begin{array}{c}\text { Kemiringan } \\
\text { Dasar } \\
\text { Saluran }\end{array}$ & $\begin{array}{c}\text { Kemiringan } \\
\text { Dinding } \\
\text { Saluran }\end{array}$ & $\begin{array}{c}\text { Luas } \\
\text { Penampang }\end{array}$ & $\begin{array}{c}\text { Panjang } \\
\text { Keliling } \\
\text { Basah }\end{array}$ & $\begin{array}{c}\text { Radius } \\
\text { Hidraulik }\end{array}$ \\
\cline { 3 - 10 } & $b(m)$ & $h(m)$ & $S o$ & $n$ & $m$ & $A(m 2)$ & $P(m)$ & $R(m)$ \\
\hline Gambang & Trapesium & 7,2 & 0,68 & 0,00025 & 1 & 2 & 5,27 & 9,99 & 0,53 \\
\hline Nambongan & Trapesium & 8,7 & 0,53 & 0,0004 & 1 & 2 & 4,56 & 10,81 & 0,42 \\
\hline Mayangan & Trapesium & 7,8 & 0,75 & 0,00007 & 1 & 2 & 3,05 & 9,40 & 0,32 \\
\hline Donokitri & Trapesium & 6,87 & 0,59 & 0,0001 & 1 & 2 & 5,22 & 9,74 & 0,54 \\
\hline Trini & Trapesium & 6,32 & 0,55 & 0,0002 & 1 & 2 & 4,08 & 8,78 & 0,46 \\
\hline Kutuasem & Trapesium & 6,3 & 0,37 & 0,00015 & 1 & 2 & 2,47 & 7,88 & 0,31 \\
\hline
\end{tabular}

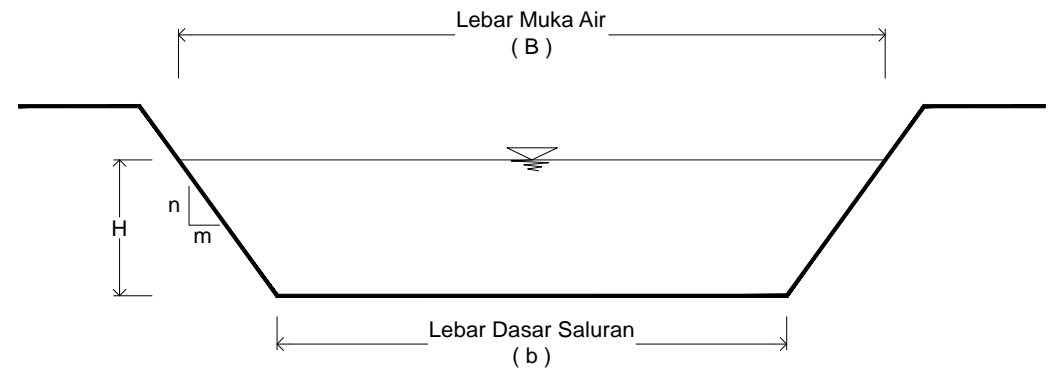

Gambar 4. Profil penampang saluran

Berdasarkan hasil analisis kestabilan dasar saluran yang ditampilkan pada Tabel 2, dapat dilihat bahwa nilai tegangan geser aliran $\left(\tau_{0}\right)$ pada masing-masing ruas penampang saluran yang ditinjau lebih besar dibandingkan dengan nilai tegangan geser kritik $\left(\tau_{c}\right)$. Kondisi tersebut mengindikasikan bahwa terjadi angkutan sedimen pada masingmasing ruas penampang saluran irigasi yang berdampak terhadap terjadinya erosi pada dasar saluran. Afiato (2016) menjelaskan bahwa hasil pengukuran konsentrasi sedimen layang pada saluran irigasi Mataram Yogyakarta menunjukkan konsentrasi sedimen suspensi akan semakin besar apabila mendekati dasar saluran dan konsentrasi sedimen suspensi rata-rata vertikal cenderung semakin besar ke area tengah penampang saluran. Sedangkan pada area belokan konsentrasi sedimen suspensi ratarata tampang pada inner bank cenderung lebih besar daripada di outer bank (Maini, 2016).

\section{Kuantitas Angkutan Sedimen}

Kuantitas angkutan sedimen yang terjadi pada setiap ruas penampang didekati melalui pendekatan teoritik. Faktor parameter tinggi kekasaran dasar hidrolik $\left(\mathrm{k}_{\mathrm{s}}\right)$ ditentukan melalui persamaan (14). Nilai koefisien 
kekasaran dasar (C) dan friction factor $\left(C_{d 90}\right)$ ditentukan menggunakan persamaan (12) dan (13) untuk masing-masing lokasi ruas penampang. Parameter kekasaran dasar $(\mu)$ pada ruas penampang saluran ditentukan melalui persamaan (11).

Tabel 2. Kontrol kestabilan partikel butiran dasar saluran

\begin{tabular}{|c|c|c|c|c|c|c|c|}
\hline \multirow{2}{*}{ No } & \multirow{2}{*}{$\begin{array}{c}\text { Parameter Awal } \\
\text { Gerak Butiran }\end{array}$} & \multicolumn{6}{|c|}{ Lokasi Penampang Saluran } \\
\hline & & Gambang & Nambongan & Mayangan & Donokitri & Trini & Kutuasem \\
\hline 1 & $u_{*}(m / d e t)$ & 0,04 & 0,043 & 0,016 & 0,025 & 0,033 & 0,023 \\
\hline 2 & $\tau_{0}\left(N / m^{2}\right)$ & 1,29 & 1,855 & 0,246 & 0,628 & 1,079 & 0,520 \\
\hline 3 & $R_{e}$ & 7,19 & 2,584 & 0,941 & 1,629 & 1,971 & 1,368 \\
\hline 4 & $\tau_{c}\left(N / m^{2}\right)$ & 0,12 & 0,049 & 0,088 & 0,085 & 0,059 & 0,088 \\
\hline \multirow[b]{2}{*}{5} & \multirow[b]{2}{*}{$\begin{array}{c}\text { Kontrol } \\
\text { Kestabilan }\end{array}$} & $\tau_{0}>\tau_{c}$ & $\tau_{0}>\tau_{c}$ & $\tau_{0}>\tau_{c}$ & $\tau_{0}>\tau_{c}$ & $\tau_{0}>\tau_{c}$ & $\tau_{0}>\tau_{c}$ \\
\hline & & $\begin{array}{c}\text { Partikel } \\
\text { Bergerak / } \\
\text { Erodible Bed }\end{array}$ & $\begin{array}{c}\text { Partikel } \\
\text { Bergerak / } \\
\text { Erodible Bed }\end{array}$ & $\begin{array}{c}\text { Partikel } \\
\text { Bergerak / } \\
\text { Erodible Bed }\end{array}$ & $\begin{array}{c}\text { Partikel } \\
\text { Bergerak / } \\
\text { Erodible } \\
\text { Bed }\end{array}$ & $\begin{array}{c}\text { Partikel } \\
\text { Bergerak / } \\
\text { Erodible } \\
\text { Bed }\end{array}$ & $\begin{array}{c}\text { Partikel } \\
\text { Bergerak / } \\
\text { Erodible } \\
\text { Bed }\end{array}$ \\
\hline
\end{tabular}

Kuantitas angkutan sedimen diperhitungkan dengan menggunakan persamaan Einstein, Meyer-Peter Muller, dan Frijlink. Berdasarkan perhitungan menggunakan persamaan-persamaan tersebut dihasilkan kuantitas angkutan sedimen yang bervariasi. Kuantitas angkutan sedimen hasil perhitungan dinyatakan dalam satuan debit angkutan partikel sedimen pada setiap ruas penampang yang ditinjau. Hasil perhitungan kuantitas angkutan sedimen pada masingmasing persamaan kemudian digunakan sebagai interpretasi nilai kuantitas angkutan sedimen yang terjadi pada saluran irigasi Mataram Yogyakarta. Hasil perhitungan disajikan pada Tabel 3.

Berdasarkan hasil perhitungan kuantitas angkutan sedimen yang ditampilkan pada Tabel 3, maka dapat dilakukan analisa kuantitas angkutan sedimen yang terjadi pada masing-masing ruas penampang saluran. Dari 3 persamaan yang digunakan, kuantitas angkutan sedimen menunjukan nilai yang bervariasi dan dapat dilihat bahwa angkutan sedimen terjadi paling besar pada ruas saluran Gambang dan Nambongan dengan nilai berturut - turut adalah $3,57 \mathrm{~m}^{3} /$ hari dan $3,67 \mathrm{~m}^{3} /$ hari. Kedua lokasi tersebut berada di daerah hulu dari keempat lokasi tinjauan lainnya. Meskipun demikian nilai angkutan sedimen yang diperoleh berdasarkan pendekatan teoritik ini sangat bervariasi. Hal ini sangat dimungkinkan pada masingmasing ruas yang ditinjau memliki dimensi penampang dan karakteristik aliran maupun butiran sedimen yang berbeda. Interpretasi hasil perhitungan angkutan sedimen dilakukan dengan membuat kurva hubungan antara debit angkutan sedimen (qb) terhadap bilangan froude ( $f r)$ yang ditampilkan pada Gambar 8. Bilangan froude / froude number (fr) merupakan faktor tak berdimensi yang mengukur resistensi dari sebuah objek yang bergerak dalam saluran air, dimana bilangan froude ( $f r$ ) merupakan rasio antara kecepatan aliran terhadap ketinggian muka air pada saluran.

Hubungan bilangan froude / froude number (fr) terhadap kuantitas angkutan sedimen (qb) dinyatakan pada kurva logaritmik yang disajikan pada Gambar 5. Kurva logaritmik yang menghubungkan antara bilangan froude (fr) dengan kuantitas angkutan sedimen merupakan interpretasi karakteristik angkutan sedimen yang terjadi pada ruas penampang saluran irigasi Mataram Yogyakarta. Laju angkutan sedimen yang melebihi keseimbangan dapat menimbulkan beberapa masalah diantaranya adalah dapat mengurangi kapasitas aliran pada saluran pada bangunan irigasi, menghambat operasional bangunan irigasi, dan mengurangi kapasitas tampung waduk (Kironoto, 2007) 
Tabel 3. Hasil analisa kuantitas angkutan sedimen dasar (bed load) pada ruas

\begin{tabular}{|c|c|c|c|c|c|c|c|}
\hline \multirow{2}{*}{ No } & \multirow{2}{*}{ Parameter } & \multicolumn{6}{|c|}{ Lokasi } \\
\hline & & Gambang & Nambongan & Mayangan & Donokitri & Trini & Kutuasem \\
\hline 1 & Tinggi Kekasaran Dasar Saluran, m (k) & 0,007 & 0,010 & 0,011 & 0,010 & 0,013 & 0,013 \\
\hline 2 & Kondisi Dasar Saluran & $\begin{array}{l}>\mathrm{d} 50, \\
\text { Bedform } \\
\text { Dasar tidak } \\
\text { rata }\end{array}$ & $\begin{array}{l}>\mathrm{d} 50, \\
\text { Bedform } \\
\text { Dasar tidak } \\
\text { rata }\end{array}$ & $\begin{array}{l}>\mathrm{d} 50, \\
\text { Bedform / } \\
\text { Dasar tidak } \\
\text { rata }\end{array}$ & $\begin{array}{l}>\mathrm{d} 50, \\
\text { Bedform } \\
\text { Dasar tidak } \\
\text { rata }\end{array}$ & $\begin{array}{l}>\mathrm{d} 50, \\
\text { Bedform } \\
\text { Dasar tidak } \\
\text { rata }\end{array}$ & $\begin{array}{l}>\mathrm{d} 50, \\
\text { Bedform } \\
\text { Dasar tidak } \\
\text { rata }\end{array}$ \\
\hline 3 & Koefisien Kekasaran Dasar $(C) \mathrm{m}^{1 / 2} / \mathrm{s}$ & 31,63 & 31,63 & 31,63 & 31,63 & 31,63 & 31,63 \\
\hline 4 & Friction Factor $\left(C_{d 90}\right) \mathrm{m}^{1 / 2} / \mathrm{s}$ & 54,52 & 77,52 & 76,23 & 64,52 & 81,33 & 77,87 \\
\hline 5 & Rasio Koefisien Kekasaran Dasar $(\mu)$ & 0,44 & 0,26 & 0,27 & 0,34 & 0,24 & 0,26 \\
\hline 6 & Froude Number $(\mathrm{Fr})$ & 0,29 & 0,37 & 0,15 & 0,18 & 0,26 & 0,21 \\
\hline 7 & Debit angkutan sedimen $(\mathrm{qb}) \mathrm{m}^{3} /$ hari & & & & & & \\
\hline 7a) & Einstein & 3,53 & 3,67 & 0,03 & 0,87 & 1,33 & 0,27 \\
\hline 7b) & Meyer-Peter Muller (M.P.M) & 2,54 & 2,77 & 0,03 & 0,72 & 0,70 & 0,19 \\
\hline 7c) & Frijlink & 3,57 & 3,28 & 0,02 & 0,77 & 1,01 & 0,18 \\
\hline
\end{tabular}

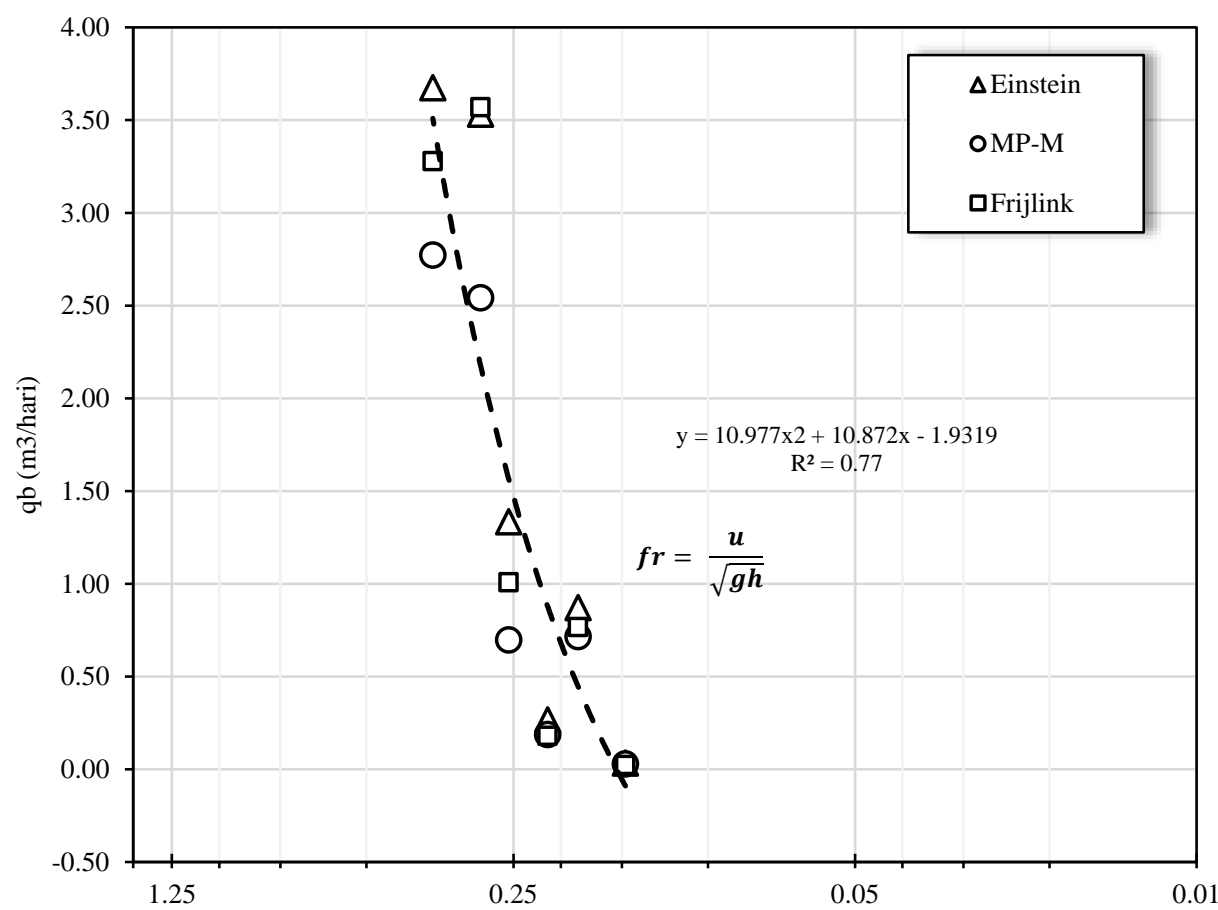

Gambar 5. Hubungan antara bilangan froude ( $f r)$ terhadap debit angkutan sedimen (qb)

\section{KESIMPULAN}

Berdasarkan analisis angkutan sedimen masing-masing lokasi ruas saluran yang ditinjau dengan menggunakan 3 persamaan, diperoleh hasil nilai kuantitas angkutan sedimen (qb) yang bervariasi, dengan nilai terbesar berada pada ruas saluran Gambang dan Nambongan dengan nilai $3,57 \mathrm{~m}^{3} /$ hari dan $3,67 \mathrm{~m}^{3} /$ hari. Kondisi kestabilan dasar kedua saluran tersebut mengalami pergerakan material dasar / erodible bed (Istiarto, 2014), sehingga sangat memungkinkan terjadinya erosi dasar 
saluran. Material hasil erosi ini nantinya akan menyebabkan terjadinya sedimentasi di bagian hilir yang kondisi kestabilan dasar nya mengalami rigid bed (Istiarto, 2014). Berdasarkan nilai angkutan sedimen tersebut dapat diestimasikan bahwa potensi sedimentasi yang akan terjadi di daerah hilir adalah sebesar $3,67 \mathrm{~m}^{3} /$ hari. Sedangkan variasi nilai kuantitas angkutan sedimen pada masing-masing lokasi sangat dipengaruhi oleh karakteristik aliran, geometri saluran, dan ukuran butiran sedimen dasar. Dengan membandingkan froude number ( $f r$ ) terhadap debit angkutan sedimen $(\mathrm{qb})$ yang dinyatakan dengan kurva logaritmik hubungan terhadap kedua variabel tersebut, diperoleh karakteristik angkutan sedimen pada saluran irigasi Mataram Yogyakarta. Kurva hubungan kedua variabel tersebut menjelaskan bahwa peningkatan bilangan froude ( $f r$ ) yang terjadi pada setiap ruas penampang saluran akan berbanding lurus terhadap peningkatan kuantitas angkutan sedimen (qb). Dengan demikian, berdasarkan penggunaan kurva logaritmik hubungan antara froude number (fr) terhadap debit angkutan sedimen (qb) dapat diperoleh karakteristik angkutan sedimen pada ruas saluran irigasi Mataram Yogyakarta.

\section{Ucapan Terimakasih}

Tulisan ini diolah dari sebagian data laporan tesis penelitian yang dilakukan sebelumnya oleh Afiato (2016) di Jurusan Teknik Sipil dan Lingkungan Fakultas Teknik UGM. Penulis juga mengucapkan terima kasih yang sebesar-besarnya kepada Institut Teknologi Nasional Yogyakarta (ITNY) atas pendanaan pada penelitian pemula berdasarkan Surat Perjanjian pelaksanaan penelitian nomor 16/ITNY/LPPMI/ Pent.Int./PP/III/2020

\section{DAFTAR PUSTAKA}

Afiato, E.N. (2016). "Distribusi Kecepatan Aliran dan Konsentrasi Sedimen Suspensi pada Aliran Tidak Seragam (Studi Kasus Saluran Mataram
Yogyakarta)". Tesis. Universitas Gadjah Mada.

Balai Besar Wilayah Sungai Serayu Opak. (2016). "Peta Daerah Irigasi Mataram Van Der Weich". Kementerian Pekerjaan Umum. Jakarta.

Carter, D.L. dan Agricultural Research Service, U. S. Department of Aviculture. (1976). "Guidelines for Sediment Control in Irrigation Return Flow". Journal of Environmental Quality, Vol. 5, No. 2.

Darly, B., Simons, et al. (2004). "Geomorphic, Hydrologic, Hydraulic and Sediment Concepts Applied To Alluvial Rivers". Colorado State University. Colorado.

Einstein, H.A. (1950). "The Bed Load Function for Sediment Transportation in Open Channel Flows". USDA Soil Conservation Service. Washington DC.

Hassanzadeh, Y. (2012). "Hydraulics of Sediment Transport”. In Tech Publisher. Tabriz Iran.

Istiarto. (2014). "Bed Load Transport Sediment". Bahan Kuliah Magister Teknik Pengelolaan Bencana Alam UGM. Yogyakarta.

Istiarto. (2014). "Awal Gerak Butir Sedimen". Bahan Kuliah Magister Teknik Pengelolaan Bencana Alam UGM. Yogyakarta.

Kironoto, B. A. (2007). "Pengaruh Angkutan Sedimen Dasar (Bed Load) Terhadap Distribusi Kecepatan Gesek Arah Transversal Pada Aliran Seragam Saluran Terbuka". Jurnal Teknik Sipil dan Lingkungan, Vol. 17, No. 2, pp. 566-579.

Meyer-Peter, E., dan Muller, R. (1948). "Formula for Bed-Load Transport". IAHSR. Stockholm.

Maini, M. (2016). "Distribusi Konsentrasi Sedimen Suspensi pada Belokan Saluran Terbuka Tampang Trapesium (Studi Kasus Saluran Mataram Yogyakarta)". Tesis. Universitas Gadjah Mada.

Putra, I. B. G. et al. (2016). “Analisis Sedimentasi pada Saluran Utama 
Bendung Jangkok". Jurnal Spektrum Sipil, Vol. 3, No. 2. pp. 208-214.

Suparman. (2011). "Sabo Untuk Penanggulangan Bencana Akibat Aliran Sedimen". Yayasan Air Adhi Eka \& JICA (Japan International Coorporation Agency). Jakarta.

Suryawan, W.A. (2008). "Kajian Angkutan Sedimen Dasar pada Saluran dengan Material Dasar Tidak Seragam”. Tesis. Universitas Gadjah Mada.

Trimble, S. W. (1997). "Contribution Contribution of Stream Channel Erosion to Sediment Yield from an Urbanizing Watershed". Journal Science, Vol. 278. 